\title{
Review \\ General Characteristics, Biomedical and Dental Application, and Usage of Chitosan in the Treatment of Temporomandibular Joint Disorders: A Narrative Review
}

\author{
Marcin Derwich ${ }^{1, *(1)}$, Lukasz Lassmann ${ }^{2}$, Katarzyna Machut $^{3}\left(\mathbb{D}\right.$, Agata Zoltowska $^{3}\left(\mathbb{D}\right.$ and Elzbieta Pawlowska $^{4}(\mathbb{D})$ \\ 1 ORTODENT, Specialist Orthodontic Private Practice in Grudziadz, 86-300 Grudziadz, Poland \\ 2 Dental Sense, Dental Private Practice in Gdansk, 80-283 Gdansk, Poland; lassmann.lukas@gmail.com \\ 3 Department of Endodontic Dentistry, Medical University of Gdansk, 80-210 Gdansk, Poland; \\ katarzyna.machut@gumed.edu.pl (K.M.); azolt@gumed.edu.pl (A.Z.) \\ 4 Department of Orthodontics, Medical University of Lodz, 90-419 Lodz, Poland; \\ elzbieta.pawlowska@umed.lodz.pl \\ * Correspondence: derwichm@tlen.pl; Tel.: +48-660-723-164
}

check for updates

Citation: Derwich, M.; Lassmann, L.; Machut, K.; Zoltowska, A.;

Pawlowska, E. General

Characteristics, Biomedical and Dental Application, and Usage of Chitosan in the Treatment of Temporomandibular Joint Disorders: A Narrative Review. Pharmaceutics 2022, 14, 305. https://doi.org/ 10.3390/pharmaceutics14020305

Academic Editor: Katarína Valachová

Received: 2 January 2022

Accepted: 21 January 2022

Published: 27 January 2022

Publisher's Note: MDPI stays neutral with regard to jurisdictional claims in published maps and institutional affiliations.

Copyright: () 2022 by the authors. Licensee MDPI, Basel, Switzerland. This article is an open access article distributed under the terms and conditions of the Creative Commons Attribution (CC BY) license (https:// creativecommons.org/licenses/by/ $4.0 /)$.

\begin{abstract}
The aim of this narrative review was to present research investigating chitosan, including its general characteristics, properties, and medical and dental applications, and finally to present the current state of knowledge regarding the efficacy of chitosan in the treatment of temporomandibular disorders (TMDs) based on the literature. The PICO approach was used for the literature search strategy. The PubMed database was analyzed with the following keywords: ("chitosan"[MeSH Terms] OR “chitosan"[All Fields] OR "chitosans"[All Fields] OR "chitosan s"[All Fields] OR "chitosane"[All Fields]) AND ("temporomandibular joint"[MeSH Terms] OR ("tem-poromandibular"[All Fields] AND “joint"[All Fields]) OR "temporomandibular joint"[All Fields] OR ("temporomandibular"[All Fields] AND “joints"[All Fields]) OR “temporo-mandibular joints"[All Fields]). After screening 8 results, 5 studies were included in this review. Chitosan presents many biological properties and therefore it can be widely used in several branches of medicine and dentistry. Chitosan promotes wound healing, helps to control bleeding, and is used in wound dressings, such as sutures and artificial skin. Apart from its antibacterial property, chitosan has many other properties, such as antifungal, mucoadhesive, anti-inflammatory, analgesic, antioxidant, antihyperglycemic, and antitumoral properties. Further clinical studies assessing the efficacy of chitosan in the treatment of TMD are required. According to only one clinical study, chitosan was effective in the treatment of TMD; however, better clinical results were obtained with platelet-rich plasma.
\end{abstract}

Keywords: chitosan; hyaluronic acid; TMD; temporomandibular joint disorders; temporomandibular joints

\section{Introduction}

Temporomandibular disorders (TMDs) is a broad term encompassing dysfunction of the temporomandibular joints (TMJs) and/or the masticatory musculature. The most important feature of TMD is pain, followed by restricted or limited jaw movement, and joint noises during jaw movement [1]. Pain-related TMD, including, among others, myalgia and arthralgia, and intra-articular TMD, including different types of disc displacements, degenerative joint disease, and subluxation [1], exist.

The overall prevalence of TMD was found to be approximately $31 \%$ for adults/elderly and $11 \%$ for children/adolescents, and the most common type of TMD is disc displacement with reduction [2]. Persistent and recurrent pain in the area of TMJs may lead to psychological discomfort, physical disability, and functional limitations, and therefore may reduce oral health-related quality of life [3-6].

The etiology of TMD is multifactorial [7]. One of the most important potential causes of TMD is mechanical overloading. Excessive intraarticular forces may cause temporary 
hypoxia in vascular-supplied structures. When the load is reduced and the intraarticular pressure decreases, blood is reperfused into the capillaries that supply the joint structures. Repeatable cycles of hypoxia and reperfusion lead to the release of free radicals into the synovial fluid. Free radicals have been found to inhibit biosynthesis of hyaluronic acid, and break down already existing chains of hyaluronic acid. Hyaluronic acid protects the phospholipids that line the surfaces of the joints and provide important hydration [8-17]. Without phospholipids, articular surfaces wear off, which leads to TMJs' destruction and so-called "sticking" [18-20]. Afterwards, non-inflammatory osseocartilaginous pathology, known as chondromalacia, develops [21,22]. Chondromalacia is reversible in its early stages. However, if the mechanical loading exceeds the capacity of the articular tissues, irreversible changes occur within the TMJs. This may lead to sticking of the articular surfaces (adherences), and eventually to disc displacements [22,23]. Figure 1 presents the schematic changes that occur within the TMJs due to mechanical overloading based on the literature [8].

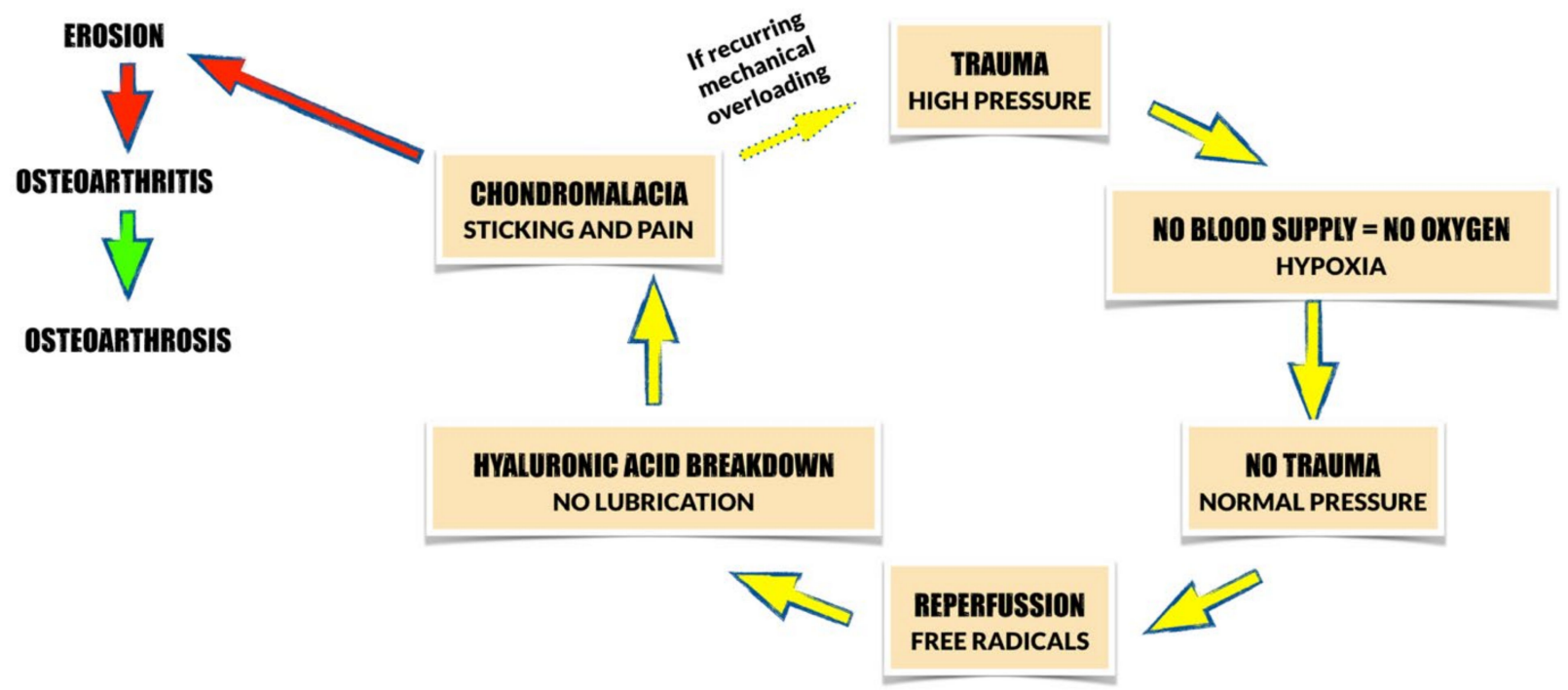

Figure 1. Schematic changes that occur within TMJs due to mechanical overloading based on the literature [8]. Yellow arrow: reversible progression; red arrow: irreversible progression; green arrow: remission.

Different treatment modalities for TMD have been discussed, including conservative methods of treatment (physiotherapy, occlusal splint therapy, pharmacotherapy), less invasive surgical procedures (arthrocentesis, intraarticular injections), and invasive surgical procedures (arthroscopy, open joint surgery) [24,25]. The choice of an adequate treatment option depends on the initial diagnosis, history of previous treatment, and intensity of reported symptoms [24,25].

Minimally invasive surgical procedures, including arthrocentesis and intraarticular injections, are very effective in TMJs' pain reduction and therefore can be recommended either additionally to conservative therapy or even as a first-line therapy [25]. Arthrocentesis can be performed either alone or in combination with intraarticular injections. So far, intraarticular injections of hyaluronic acid (HA), corticosteroids (CS), and platelet-rich plasma (PRP) have been examined. However, the results of intraarticular injections performed after arthrocentesis were not superior to the results obtained with arthrocentesis performed alone. In case of intraarticular injections performed without previous arthrocentesis, better results were obtained with HA compared to either CS or physiologic saline solution [26].

Although a lot is known about the use of HA, CS, and PRP in the treatment of TMD, none of these substances are considered to unquestionably be the gold standard. Contemporary medicine is looking for new solutions and new biomaterials for tissue regeneration. One of the very interesting materials in terms of tissue regeneration is 
chitosan, a deacetylated form of chitin, a linear semi-crystalline polymer and the most naturally abundant polysaccharide after cellulose [27,28]. Nowadays, chitosan is one bone tissue engineering scaffold. It has a similar chemical structure to glycosaminoglycans (the main components of connective tissue extracellular matrix, ECM), and it can be shaped to specific bone defects and fabricated as membranes, fibers, nanoparticles, hydrogels, or through 3D printing [29-31]. Moreover, chitosan has been found to be effective in the process of cartilage regeneration, and in relieving osteoarthritis [32-35]. Therefore, chitosan may be an effective agent in the treatment of TMD.

The aim of this narrative review was to present research investigating chitosan, including its general characteristics, properties, and medical and dental applications, and finally to present the current state of knowledge regarding the efficacy of chitosan in the treatment of TMD based on the literature.

\section{Methodology of the Literature Search Strategy}

\subsection{Clinical Question}

What is the efficacy of chitosan in the treatment of TMD in humans and animals based on the literature?

\subsection{Inclusion and Exclusion Criteria}

Table 1 presents the inclusion and exclusion criteria used for the narrative review.

Table 1. Inclusion and exclusion criteria used for the narrative review.

\begin{tabular}{ll}
\hline \multicolumn{1}{c}{ Criteria } & \multicolumn{1}{c}{ List of Specific Criteria } \\
\hline & -Randomized controlled trials \\
& -Randomized clinical trials \\
& -Case-control studies \\
& -Case reports \\
Inclusion & -Animal studies \\
criteria & -Study population: humans diagnosed with TMD, animal models \\
& - Methods of treatment: intraarticular injections of chitosan, usage \\
& of chitosan-based scaffolds placed in the TMJs \\
& -Papers written in English \\
\hline & -Comments \\
Exclusion & -Systematic reviews and metanalyses \\
criteria & -Study population: patients without the diagnosis of TMD \\
& -Methods of treatment: conservative methods of treatment \\
& (including physiotherapy, occlusal splint therapy \\
& and pharmacotherapy) \\
& -Papers written in languages other than English \\
\hline
\end{tabular}

TMD: temporomandibular joint disorder; TMJ: temporomandibular joint.

\subsection{The PICO Approach}

We used the PICO approach to properly develop literature search strategies for this review: Population:

Patients who were diagnosed with TMD, and animal models.

Intervention:

Intraarticular injections of chitosan in patients diagnosed with TMD, usage of chitosanbased scaffolds placed in TMJs

Comparison:

Intraarticular injection of other substances, including: PRP, HA, CS, arthrocentesis or arthroscopy alone, open joint surgeries, and placebo. Randomized controlled trials (RCTs), randomized clinical trials, case-control studies, case reports, and animal studies were included in the review. 
Outcome:

Increased maximum mouth opening and decreased pain in the temporomandibular joint area.

\subsection{Search Strategy}

The PubMed database was analyzed with the following keywords: ("chitosan"[MeSH Terms] OR “chitosan"[All Fields] OR "chitosans"[All Fields] OR "chitosan s"[All Fields] OR "chitosane"[All Fields]) AND ("temporomandibular joint"[MeSH Terms] OR ("temporomandibular"[All Fields] AND “joint"[All Fields]) OR “temporomandibular joint"[All Fields] OR ("temporomandibular"[All Fields] AND “joints"[All Fields]) OR "temporomandibular joints"[All Fields]). After screening 8 results, 5 studies were included in this review.

Figure 2 presents the PRISMA flow diagram for the review of the literature.

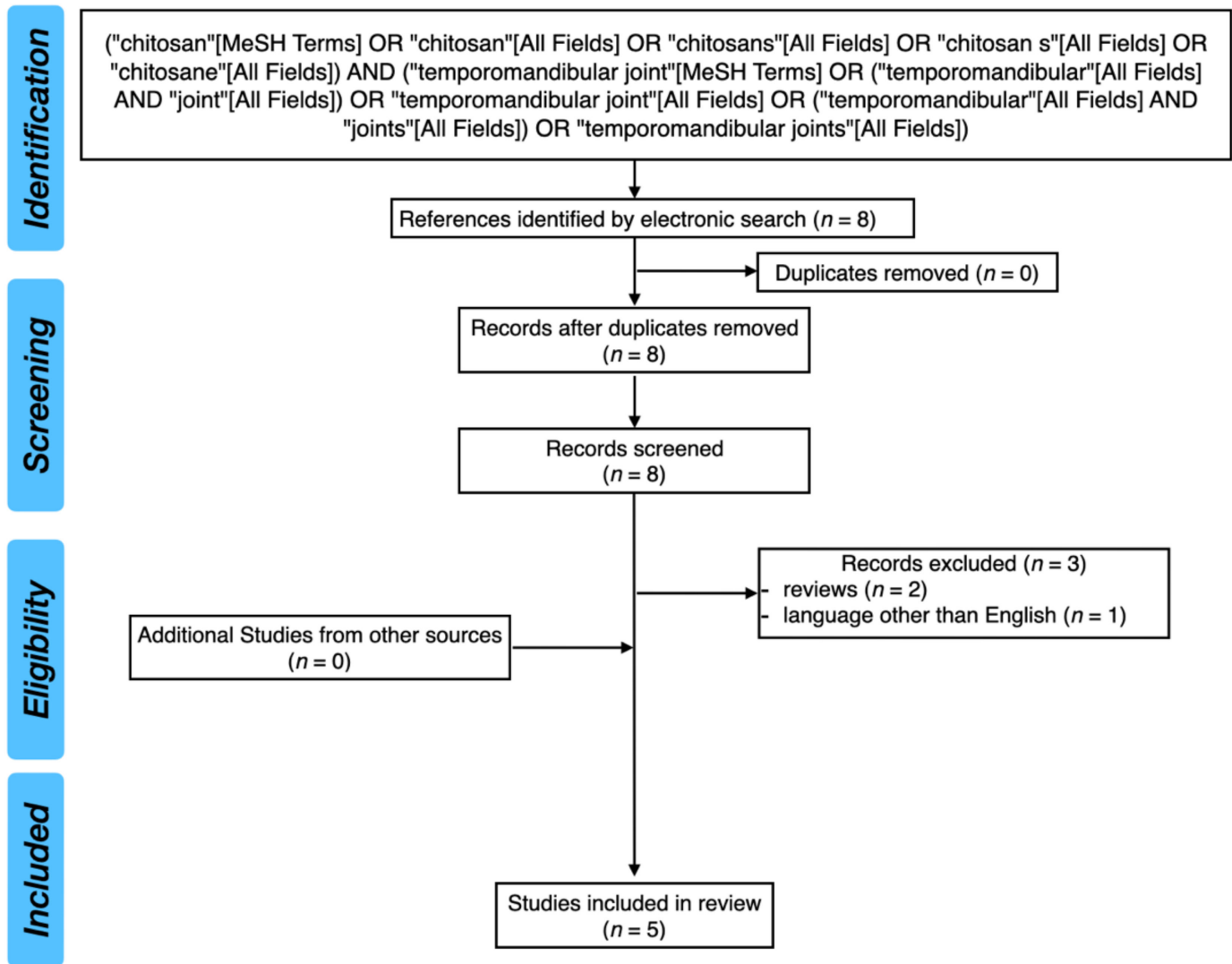

Figure 2. PRISMA flow diagram for the review of the literature.

\subsection{Cohen's Kappa Coefficient}

Cohen's kappa coefficient between the reviewers was 1.00 .

\section{Chitosan: General Characteristics}

Chitin ( $\beta-(1-4)$-poly-N-acetyl-D-glucosamine) is a natural mucopolysaccharide with a structure similar to cellulose $[36,37]$ and is one of the most common biopolymers. Chitin is a compound found in fungi cell walls and forms outer-shell structures, such as the carapaces of marine invertebrates, e.g., crabs, lobsters, and shrimps, or the exoskeletons of insects and arthropods, and endoskeletons of mollusks [29,36,37].

The first study and isolation of chitin from fungal species was made by a French chemist Henri Braconnot in 1811. Chitin is synthesized from uridine diphosphate Nacetylglucosamine (UDP-N-acetylglucosamine) by the chitin synthase $[29,38]$. Chitin has a limited range of applications as scaffolds to support tissue regeneration due to its insolubil- 
ity [39,40]. A water-soluble derivate of chitin, chitosan, is more useful in multiple fields as it is biocompatible, non-toxic, low allergenic, low immunogenic, and biodegradable [36,40]. Chitosan has been found to be an interesting material in many fields, including medicine, agriculture, food processing, nutritional enhancement, cosmetics, and waste and water treatment [41].

Chitosan is a polycationic linear polysaccharide composed of varying amounts of deacetylated $\beta-(1-4)$ glucosamine $(\mathrm{GlcN})$ and acetylated N-acetyl-glucosamine (GlcNAc) residues $[42,43]$. It is obtained from chitin in a deacetylation process with chitin deacetylase (of bacterial or fungal origin) or in an alkaline hydrolysis [40,44,45]. Figure 3 presents the reaction of chitin deacetylation.

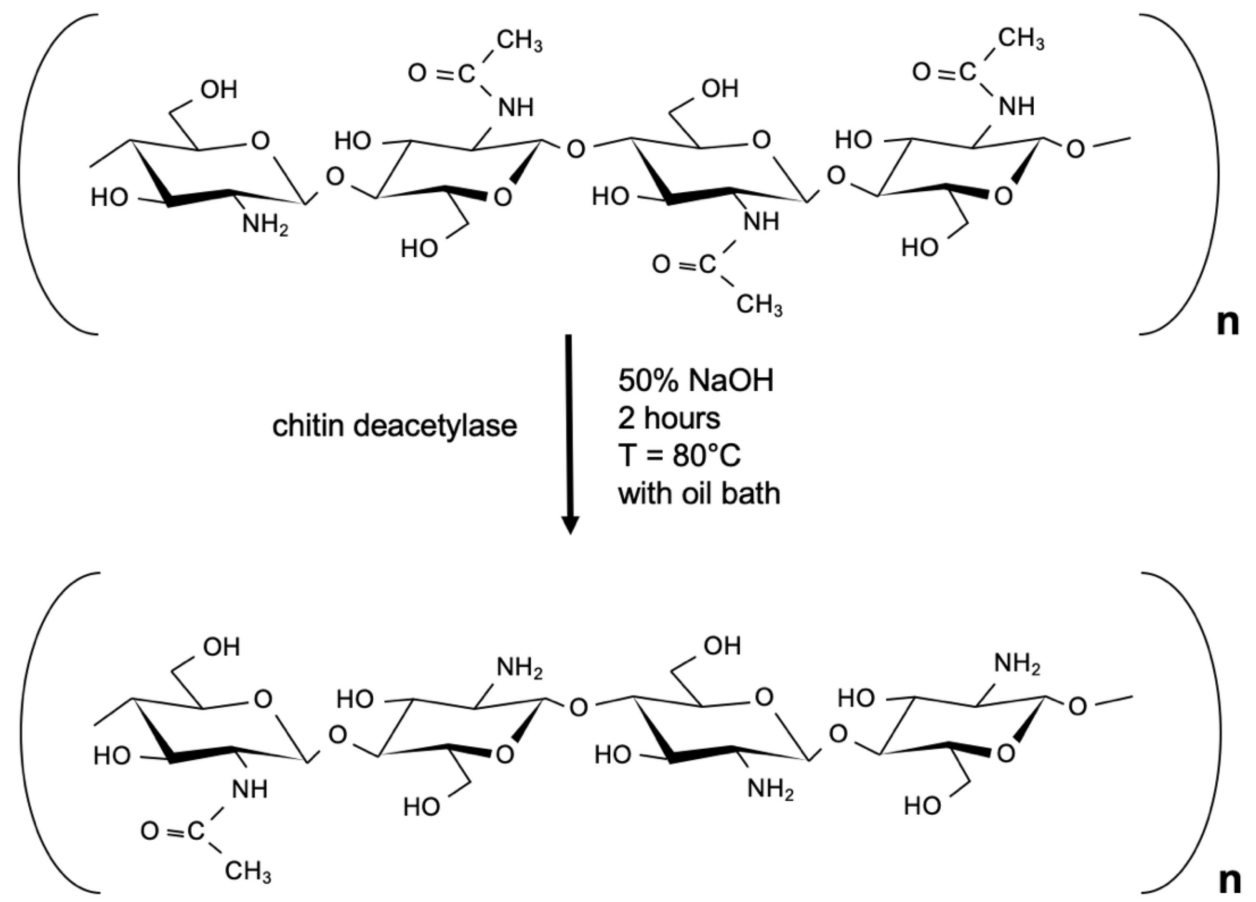

Figure 3. The reaction of chitin deacetylation with chitin deacetylase.

Chitosan was obtained for the first time by treating chitin with potassium hydroxide in the second half of the 19th century, but the chemical structure of chitosan was announced in 1950, and the name "chitosan" was proposed by Hoppe-Seyler in 1984 [36,46,47]. Fungi belonging to the classes Zygomycetes and Mucorales are capable of producing chitosan, as a natural structural element of their cell walls [47]. This natural source of chitosan is under further research for use in tissue engineering [47].

The main sources of chitosan are the carapaces of shrimps due to their small thickness. The shells are cleaned, dried, and smashed into smaller pieces. The typical protocol is divided into four steps: demineralization, deproteinization, decolorization, and deacetylation. All processes can be chemical or biological (by enzymatic proteolysis or bacterial fermentation). For biomedical use, the final product has to be purified [48].

The final reaction of chitin deacetylation is usually incomplete and chitosan contains acetamide groups. The presence of an amine group on each deacetylated unit in weak acidic solution $\left(\mathrm{H}^{+}\right)$can be positively charged $\left(\mathrm{NH}^{+}\right)$. The positive electric energy on the surface of chitosan in an acidic environment makes it possible to form complexes with other synthetic or natural polymers, and also makes chitosan soluble. These physicochemical properties ensure it biocompatibility and bacteriostasis and the promotion of cell growth $[49,50]$. Chitosan can be enzymatically degraded by the family of enzymes named chitosanases. Chitosanases are glycosyl hydrolases that break $\beta-1,4$-glycosidic bonds [51]. 
The positive electric charge density depends on the degree of deacetylation (\% DD), which is described by the percentage of the molar fraction of deacetylated units, environmental $\mathrm{pH}$, and molecular weights, which range from 300 to more than 1000 kilodaltons [42,52]. Chitosan oligomers are soluble over a wide $\mathrm{pH}$ range, but chitosan with a higher molecular weight chitosan forms with a higher \% DD are only soluble in acidic solutions $[29,30,50]$.

Chitosan can bind with cholesterol, triglycerides, proteins, and metal ions, so it is commonly used as a chelating agent. Moreover, the cationic chitosan can easily bind negatively charged molecules, such as plasmid DNA. The DNA-chitosan nanoparticles (DNA-CS NP) are small-sized complexes, ranging from 20 to $500 \mathrm{~nm}$, and can be transported into the cell through endocytosis or pinocytosis, and are stable during oral delivery. DNACS has been used in gene delivery therapy in orthopedic bone regeneration [53-56].

Chitosan is able to promote the accumulation of anionic platelets and erythrocytes, so it is useful for controlling bleeding and is used in wound dressings, such as sutures and artificial skin, which has been approved by the Food and Drug Administration (FDA). The antibacterial property of chitosan is also useful in wound healing, due to the ability to form electrostatic interactions between chitosan's positive charge groups and anions presented on the cell wall (bacterial growth inhibition). This effect lasts up to 7 days [57].

Apart from its antibacterial property, chitosan has many others, such as antifungal, mucoadhesive, anti-inflammatory, analgesic, antioxidant, antihyperglycemic, and antitumoral properties. All the aforementioned abilities are used in medicine, for example, in periodontology, guided tissue engineering, dermatology, and pharmacology (in drug delivery systems) [53,54,58,59].

\section{Chitosan in Comparison to Hyaluronic Acid}

Chitosan and hyaluronic acid (HA) are polysaccharides with similar biochemical structures [60]. However, some differences between these molecules exist and therefore it seems rational to compare their structures and properties.

HA, also known as hyaluronan, is a naturally occurring non-sulfated mucopolysaccharide in human connective, epithelial, and neural tissues [61,62]. HA is part of the glycosaminoglycans (GAG) family and it is the only mucopolysaccharide that is synthesized on the inner surface of the cell membrane rather than in the Golgi apparatus. HA is synthesized by HA synthases. The HA molecule is anionic and it is composed of repeating units of disaccharides: D-glucuronic acid and $\mathrm{N}$-acetylglucosamine, which are bonded by $\beta-(1-4)$ and $\beta-(1-3)$ glycosides linkages [61-63]. Figure 4 presents the skeletal structure of HA.

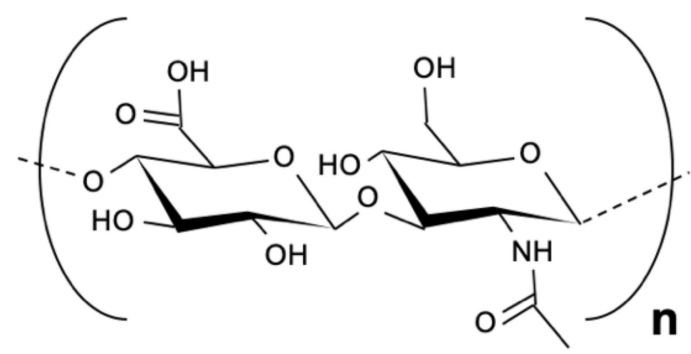

Figure 4. The skeletal structure of hyaluronic acid.

HA presents significant water solubility and hydrophilicity, due to its ability to bind water molecules [64].

In some stress conditions, such as injury, high molecular weight HA (HMWHA) can be fragmented into smaller chains, known as low molecular weight HA (LMWHA). Probably, LMWHA is a proinflammatory molecule, in contrast to HMWHA, which has well-documented anti-inflammatory and immunosuppressive properties [65]. 
The catabolism of HA chains can be either enzymatic with hyaluronidases from the hydrolysis family, or chemical. There are three enzymatic isoforms of hyaluronidase: hyaluronidase-1 (HYAL-1), hyaluronidase-2 (HYAL-2), and hyaluronidase-3 (HYAL-3). The chemical degradation is caused by reactive oxygen forms. These free-radicals of HA degradation can be prevented by superoxide dismutase $[63,66]$.

Existing studies have indicated that HA has good biocompatibility and a broad distribution of HA receptors within the whole body. These abilities have been successfully applied in many branches of medicine. HA derivates are commonly used in orthopedics as a joint lubricant, osteoarthritis or rheumatoid arthritis therapy, aesthetic dermatology as dermal filler, ophthalmology in corneal wound healing, or the treatment of dry eye syndrome. HA is widely used in drug delivery systems [63,66-68]. HA can also be used in dentistry to help in periodontal tissue healing, as a topical gel in gingivitis and chronic periodontitis treatment, and in reducing postoperative pain after surgical procedures (such as implant and sinus lift). Moreover, HA shows osteoinductive properties, which are used during the regeneration of bone defects. HA is recommended in the therapy of mouth dryness, for example, in Sjorgen's syndrome [69,70].

Table 2 presents a comparison of the physical and biochemical properties of chitosan and HA based on the literature.

Table 2. Comparison of the physical and biochemical properties of chitosan and HA based on the literature.

\begin{tabular}{|c|c|c|}
\hline $\begin{array}{l}\text { Comparable } \\
\text { Characteristic } \\
\text { [References] }\end{array}$ & Chitosan & Hyaluronic Acid \\
\hline $\begin{array}{l}\text { Chemical structure } \\
{[36,37,61,62]}\end{array}$ & $\begin{array}{l}\text { mucopolysaccharide; } \\
\text { deacetylated glucosamine (GlcN) and } \\
\text { acetylated N-acetyl-glucosamine } \\
\text { (GlcNAc) }\end{array}$ & $\begin{array}{l}\text { mucopolysaccharide; } \\
\text { D-glucuronic acid (D-GlcA) and } \\
\text { N-acetylglucosamine (GlcNAc) }\end{array}$ \\
\hline $\begin{array}{l}\text { Electric charge } \\
{[42,62]}\end{array}$ & cationic & anionic \\
\hline $\begin{array}{l}\text { Glycoside linkages } \\
{[36,37,42,61-64,66]}\end{array}$ & $\beta-(1-4)$ & $\beta-(1-4)$ and $\beta-(1-3)$ \\
\hline $\begin{array}{l}\text { Origin } \\
{[29,36,37,61,62,71]}\end{array}$ & $\begin{array}{l}\text { chitin ex. shells of shrimp or other } \\
\text { crustaceans }\end{array}$ & $\begin{array}{l}\text { 1. ECM of vertebrate's tissue, } \\
\text { 2. bacterial sources, } \\
\text { 3. chemoenzymatic sources }\end{array}$ \\
\hline $\begin{array}{l}\text { Appearance } \\
{[44,64]}\end{array}$ & $\begin{array}{l}\text { white or gray, translucent flake or powder } \\
\text { solid, tasteless, odorless, non-toxic }\end{array}$ & transparent, viscous fluid or white powder \\
\hline $\begin{array}{l}\text { Molecular weight } \\
{[42,64]}\end{array}$ & $300-1000 \mathrm{kDa}$ & $4-20,000 \mathrm{kDa}$ \\
\hline $\begin{array}{l}\text { Degradation enzyme } \\
{[51,63,66]}\end{array}$ & chitosanases (hydrolasis) & hyaluronidases (hydrolasis) \\
\hline $\begin{array}{l}\text { Solubility } \\
{[29,50,64,71]}\end{array}$ & only in solutions of $\mathrm{pH} \leq 7$ & $\begin{array}{l}\text { good in organic and inorganic solutions; } \\
\text { HA depolimerizes when } 4<\mathrm{pH}<11\end{array}$ \\
\hline $\begin{array}{l}\text { Physiochemical } \\
\text { properties } \\
{[36,37,40,42,61-63,66,71]}\end{array}$ & $\begin{array}{l}\text { depend on molecular weight and } \\
\text { acetylation degree: } \\
\text { 1. bioadhesive, } \\
\text { 2. biocompatible, } \\
\text { 3. biodegradable }\end{array}$ & $\begin{array}{l}\text { 1. viscosity, } \\
\text { 2. elasticity, } \\
\text { 3. lubrication, } \\
\text { 4. a high capacity for holding water, } \\
\text { 5. biocompatible, } \\
\text { 6. biodegradable, } \\
\text { 7. bioadhesive }\end{array}$ \\
\hline
\end{tabular}


Table 2. Cont.

\begin{tabular}{|c|c|c|}
\hline $\begin{array}{l}\text { Comparable } \\
\text { Characteristic } \\
\text { [References] }\end{array}$ & Chitosan & Hyaluronic Acid \\
\hline $\begin{array}{l}\text { Biological properties } \\
{[37,57,59,72,73]}\end{array}$ & $\begin{array}{l}\text { 1. mucoadhesive, } \\
\text { 2. bactericidal, } \\
\text { 3. fungicidal activity, } \\
\text { 4. wound healing potential } \\
\text { 5. antioxidant activity, } \\
\text { 6. cholesterol and triglyceride trapping, } \\
\text { 7. hypoglycemic effects }\end{array}$ & $\begin{array}{l}\text { depend on the molecular size of HA: } \\
\text { 1. regulation of cell division, migration, differentiation; } \\
\text { 2. HA is an extracellular transmitting molecule in } \\
\text { signaling pathways; } \\
\text { 3. participates in tissue regeneration and inflammation } \\
\text { 4. provides structural framework for cells }\end{array}$ \\
\hline
\end{tabular}

ECM: extracellular matrix; HA: hyaluronic acid.

\section{Properties of Chitosan and its Biomedical Application}

The antimicrobial activity of chitosan was first described by Allan and Hadwiger [74]. Two potential antimicrobial mechanisms have been identified depending on chitosan's molecular weight. Low molecular weight (LMW) chitosan has been found to penetrate bacterial walls, bind with DNA, and control gene expression. Contrary to this, high molecular weight (HMW) chitosan binds with negatively charged components on the bacterial cell wall, forming a polymer membrane that prevents nutrients from entering the cell $[75,76]$.

The process of wound healing comprises five overlapping stages, namely: homeostasis, inflammation, migration, proliferation, and maturation [77]. Immediately after the application of chitosan to a fresh wound, the immune system is activated, the number of cytokines released from thrombocytes increases, and formation of a blood clot is accelerated. Next, leukocyte phagocytosis is caused by vascular endothelial cell activity and granulocyte migration. Macrophages turn into giant cells that break down large amounts of collagen, which prevents scarring. As a result of the contact between migrating leukocytes and chitosan, physiologically active substances are released, which consequently intensifies the activity of monocytes, macrophages, vascular endothelial cells, and fibroblasts. The cascade of these reactions promotes the formation of granulation tissue and stimulates angiogenesis [78].

Chitosan also has the ability to inhibit matrix metalloproteinases (MMPs), enzymes capable of degrading components of the extracellular matrix, including collagens, laminin, and fibronectin [79]. MMPs play a significant role in processes related to tissue remodeling, including wound healing, arthritis, and neoplastic changes, significantly impeding regenerative processes. The inhibitory effect of chitosan on MMPs has been explained as the interaction between two mechanisms: inhibition of MMPs' expression at the transcriptional level, and limitation of the access to zinc ions, which are considered to be cofactors of MMPs [80,81]. Shikhman et al. [82] showed that the chondroprotective efficacy of GlcNAc was better than viscosupplementation treatment with hyaluronan.

Figure 5 presents the exemplary mechanism of treatment of rheumatoid arthritis (RA) with chitosan. Inflammation of the synovial membrane within the joint is initiated by an unknown trigger. Autoreactive lymphocytes and macrophages are attracted to the inflamed tissue. Next, autoreactive CD4 T cells activate macrophages, which results in the production of proinflammatory cytokines. Proinflammatory cytokines activate fibroblasts to produce MMPs. The tumor necrosis factor (TNF) family cytokine receptor activator for nuclear factor $\mathrm{k} B$ ligand (RANK ligand) is the primary activator of bone-destroying osteoclasts. Intraarticular injection of chitosan promotes cartilage formation, inhibits MMPs, regulates the redox environment, stimulates angiogenesis, and initiates the healing processes [83]. 


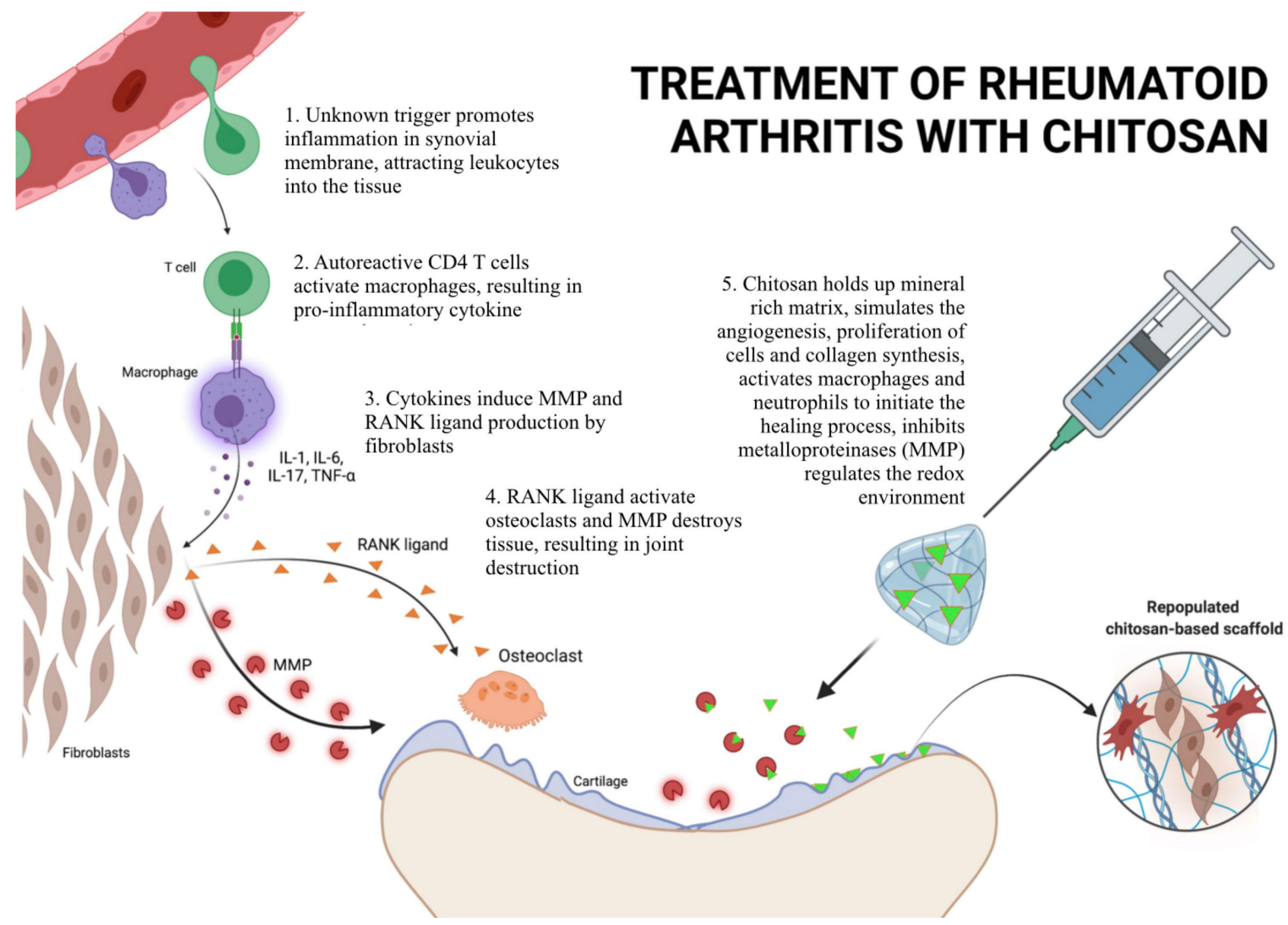

Figure 5. Treatment of rheumatoid arthritis with chitosan based on the literature [83]. IL-1: interleukin 1; IL-6: interleukin 6; IL-17: interleukin 17; MMP: matrix metalloproteinases; RANK ligand: Receptor Activator for Nuclear Factor к B Ligand; T cell: lymphocyte type T; TNF $\alpha$ : tumor necrosis factor $\alpha$. Figure 5 was created with BioRender.com. (accessed on 17 December 2021.).

Articular cartilage presents limited repair capacity [84]. The structure of chitosan is similar to the structure of the repeating polysaccharide units in articular cartilage [85,86], making the characteristics of chitosan similar to those of hyaluronic acid and GAG in the ECM [87]. These GAG-analogous structures are also involved in the synthesis of chondroitin sulfate, HA, and collagen type II [88]. Therefore, chitosan, especially in the form of a hydrogel [89], can simulate the ECM of articular cartilage and promote cartilage formation as a natural scaffold for repairing cartilage defects [90]. These unique properties of the chitosan scaffold are related to the size and orientation of the chitosan pores [85]. The properties of chitosan in wound healing also include the ability to stimulate the production of fibroblasts by the fibroblast growth factor [91]. To sum up, the justification for using chitosan in bone tissue engineering is its ability to maintain mineral-rich matrix deposition, and its osteoconduction, biocompatibility, and biodegradability [52].

Moreover, many studies have shown that chitosan and its derivatives also present antitumor activity [92], which has been found to be related to the increase in lymphokine production resulting in the proliferation of cytolytic T cells [93]. It is supposed that the increased secretion of IL-1 and IL-2 may cause an anti-tumor effect through the maturation and infiltration of cytolytic T lymphocytes [94]. However, other studies have shown that chitosan may also directly affect cancer cells and may inhibit tumor cell proliferation by caspase-3 induced apoptosis $[95,96]$.

Figure 6 summarizes the medical application of chitosan based on the literature [74-101]. 


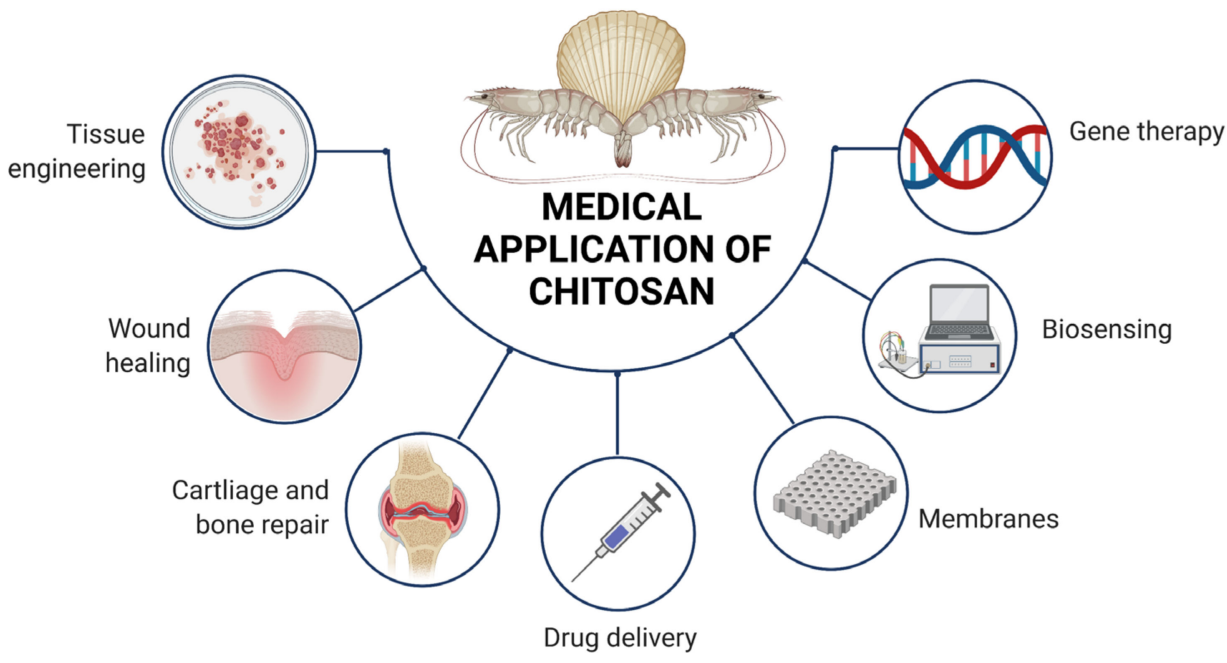

Figure 6. Medical application of chitosan based on the literature [74-101]. Figure 6 was created with BioRender.com. (accessed on 17 December 2021.).

\section{Chitosan Application in Dentistry}

Figure 7 schematically presents the application of chitosan in dentistry based on the literature [102-116].

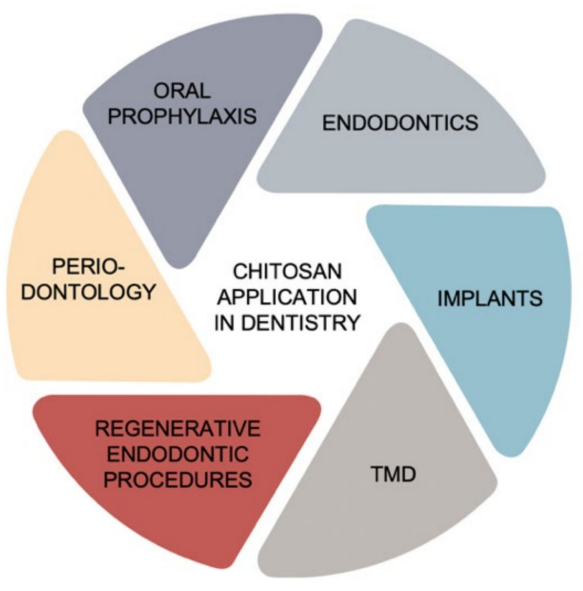

Figure 7. Application of chitosan in dentistry based on the literature [102-116]. TMDs: temporomandibular joint disorders.

\subsection{Oral Prophylaxis}

Chitosan's cationic groups interact with negative-charge components of bacteria's cell surface. Chitosan is known to have better inhibitory (bactericidal and bacteriostatic) effects on Gram-negative than Gram-positive bacteria [102]. Moreover, chitosan's amino groups $\left(\mathrm{NH}^{+}\right)$may neutralize the acidic environment within dental plaque and therefore chitosan is able to maintain the $\mathrm{pH}$ of plaque above the critical value required for enamel demineralization [103].

Costa et al. [104] found that chitosan-based mouthwash could inhibit microbial adhesion (Enterococcus faecalis, S. mutans, Candida albicans, and Prevotella intermedia), and biofilm formation while at the same time promoting the dissolution of already formed bacterial colonies. These results suggest that chitosan-based mouthwash can be used for prophylaxis of dental caries, periodontitis, and candidiasis.

Finally, chitosan has been found to interact with hydroxyapatite on the tooth surface. This property of chitosan, especially with nanoparticles, can inhibit biofilm formation on enamel and dentin, and indirectly prevent tooth demineralization [105]. In addition to 
this, chitosan is also able to penetrate the enamel and rebuild demineralized enamel and prevent the progression of demineralization [106].

\subsection{Endodontics}

Root canal treatment (RCT) is performed to remove inflamed or necrotic pulp infected by bacteria and to chemo-mechanically debride the root canal system [107]. Several reports have been published regarding the antibacterial activity of chitosan with nanoparticles (CSNPs) against pathogenic species, including S. mutans, E. faecalis, and P. gingivalis. Due to their potential benefits, CSNPs could be added to calcium hydroxide for temporary root canal filling or to endodontic sealers [106,108].

Chitosan has also been used in regenerative endodontic procedures [109]. Chitosanbased porous scaffolds can be enriched with growth factors and bioactive molecules. Released signaling biomolecules increase the expression of odontoblastic markers, such as dentin sialophosphoprotein, dentin matrix acidic phosphoprotein, and alkaline phosphate, which induce proliferation of dental pulp steam cells (DPSCs) and differentiation into odontoblasts [106]. Innovative chitosan-based scaffolds containing the bioactive molecules bone morphogenetic proteins (BMPs) and transforming growth factor- $\beta 1$ (TGF- $\beta 1$ ) have been found to promote cell adhesion, differentiation and proliferation of DPSCs, and odontoblast-like cells [106,110].

\subsection{Periodontology}

Chitosan can be used as a scaffold for the regeneration of periodontal tissues (in the treatment of periodontal pockets), because of its good biocompatibility, degradability by naturally occurring enzymes, appropriate physicochemical properties, and optimal molecule size. Injectable hydrogels with chitosan membranes can potentially be applied in drug delivery systems or in tissue engineering [106,111-114].

Moreover, chitosan scaffolds can be seeded by multi-potent dental mesenchymal stem cells, such as stem cells from human exfoliated deciduous teeth (SHED) and human periodontal ligament cells (HPLCs). This application of chitosan can be successfully used in periodontal tissue regeneration by activating cementoblasts and osteoblasts to form new tissue $[115,116]$.

\subsection{Implantology}

Modifications of implant surfaces with chitosan are still being examined in terms of healing processes and osseointegration [98]. The degree of deacetylation (DDA\%) may be crucial for improvement of the osteoinductive properties of chitosan coatings. Alnufaiy et al. [117] noticed that an increase in the DDA of chitosan coatings stimulated biomineralization and the formation of new osteoblasts.

\section{Chitosan in the Treatment of TMD}

Only three studies (one human and two animal studies) analyzing the efficacy of chitosan in the treatment of TMD were found.

$\mathrm{Li}$ et al. [118] retrospectively analyzed a group of 27 patients diagnosed with TMJ OA. In total, 15 patients ( 13 female and 2 male) were treated with 3 intraarticular injections of $1.0 \mathrm{~mL}$ of chitosan (1 intraarticular injection once per month). The remaining 12 patients (11 female and 1 male) were treated with 3 intraarticular injections of $1.0 \mathrm{~mL}$ of PRP. The authors analyzed the maximal interincisal opening (MIO), pain intensity, and TMJ sounds before the onset of the treatment, and 3 and 6 months after the end of the treatment. $\mathrm{Li}$ et al. [1] noticed that although MIO improved significantly in both groups during the observation period, significantly better results were obtained in the PRP group. However, it should also be emphasized that the average value of MIO before the onset of the treatment differed between the examined groups and was larger in patients from the PRP group. Pain intensity decreased in both groups throughout the observation period. However, significantly lower pain intensity at 6 months after the treatment was observed in patients 
treated with PRP compared to the chitosan group. Both groups reported relief of TMJ sounds. There were no statistically significant differences between the groups regarding the relief of TMJ sounds nor regarding the condylar bone reconstruction after the end of the treatment. Finally, complications after the intraarticular injections were observed only in the PRP group, including pain and swelling in the area of TMJ, and changes in the occlusion. All complications were transient.

Talaat et al. [119] performed an animal study in which they assessed the efficacy of thermosensitive hydrogels based on chitosan in terms of intraarticular controlled release of drugs in the rabbit temporomandibular joint. In total, 13 adult male rabbits were included into the study. The authors injected $0.2 \mathrm{~mL}$ of chitosan/ $\beta$-glycerophosphate/hyaluronic acid into the rabbits' left TMJs and $0.2 \mathrm{~mL}$ of control solution of hyaluronic acid into the rabbits' right TMJs. Talaat et al. observed that the mean percentage of retention of hyaluronic acid was significantly higher within the TMJs injected with chitosan-based hydrogels compared to the controls ( $35.61 \pm 6.68$ vs. $12.13 \pm 1.85, p<0.001)$. According to the studies on the rabbit model, chitosan-based thermosensitive hydrogel appears to be an efficient controlled drug release system to the TMJ.

$\mathrm{Li}$ et al. [120] analyzed the effects of chitosan membrane on postsurgical TMJs' intraarticular adhesions in goats with released retrodiscal tissues and therefore with completely displaced TMJ articular discs. The authors examined six goats. All of the goats underwent open joint surgeries, during which the retrodiscal tissues were cut off. Two of the goats served as a control, with no other additional surgeries or treatments performed. Four goats form the experimental group received a chitosan membrane during surgery, which was placed within the inferior joint space. According to the authors, chitosan membranes appeared to act as a barrier preventing adhesions, but the chitosan membranes also protected the condyles from damage. Moreover, the experimental group presented smooth condylar surfaces, with no hyperemia or adhesion, and significantly greater maximum passive mouth opening compared to the control group. The control group was diagnosed with severe intraarticular adhesions.

Table 3 presents the effectiveness of chitosan used in the treatment of TMD from in vivo studies [118-120].

Two studies analyzing the use of chitosan-based scaffolds in terms of tissue engineering in the treatment of TMD have also been published.

Bousnaki et al. [121] noticed that chitosan/alginate scaffolds stimulated the attachment and proliferation of dental pulp stem cells (DPSCs) and human nucleus pulposus cells (hNPCs). Moreover, DPSCs, which were cultured in chitosan/alginate scaffolds, presented increased expression of fibrocartilaginous markers. Therefore, the chitosan/alginate scaffolds were expected to be useful in regeneration in TMJ disc tissue by producing fibrocartilage tissue.

Tissue engineering using chitosan for the treatment of TMJ disorders was also analyzed by Wu et al. [122]. The authors found that synovium-derived mesenchymal stem cells (SDSCs) seeded in a fibrin/chitosan scaffold synthesized a fibrocartilage extracellular matrix. Wu et al. [122] indicated that above-described regenerative properties of SDSCs seeded in a fibrin/chitosan scaffold could be used for repairing TMJ articular disc perforation. The authors also emphasized that the cell seeding efficiency was significantly improved by using fibrin gel. There were significantly more SDSCs seeded in the fibrin/chitosan scaffold compared to the pure chitosan scaffold. However, the authors decided to combine fibrin gel with a porous chitosan scaffold to increase both the cell differentiation and synthesis of the extracellular matrix, and to support the fixation of the scaffold within the site of the disc defect using the adhesive properties of fibrin gel. 
Table 3. Effectiveness of chitosan used in the treatment of the TMD from the in vivo studies [118-120].

\begin{tabular}{|c|c|c|c|}
\hline Reference & Study Design & Participants and Intervention & Endpoint and Results \\
\hline Li et al. [118] & $\begin{array}{l}\text { Retrospective, } \\
\text { case control } \\
\text { study }\end{array}$ & $\begin{array}{l}27 \text { patients ( } 24 \text { women, } 3 \text { men, aged } \\
25.74 \pm 9.75 \text { ): } \\
\text { - chitosan group ( } 15 \text { patients): } \\
3 \text { intraarticular injections of } 1.0 \mathrm{~mL} \text { of } \\
\text { chitosan once a month for } 3 \text { months } \\
\text { - PRP group ( } 12 \text { patients): } 3 \text { intraarticular } \\
\text { injections of } 1.0 \mathrm{~mL} \text { of PRP once a month } \\
\text { for } 3 \text { months }\end{array}$ & $\begin{array}{l}\text { Endpoint: } 6 \text { months } \\
\text { MIO improved significantly in both groups, } \\
\text { significantly better results presented PRP } \\
\text { group. Pain intensity decreased in both } \\
\text { groups, significantly lower pain intensity at } \\
6 \text { months after the treatment presented } \\
\text { PRP group. } \\
\text { Both of the groups reported relief of } \\
\text { TMJ sounds. } \\
\text { Complications after intraarticular injections } \\
\text { were observed only in the PRP group. }\end{array}$ \\
\hline
\end{tabular}

13 adult male New Zealand white rabbits (18 weeks old on average; mean weight of $2.5 \mathrm{~kg}$ )

- study group (left TMJs) injection of $0.2 \mathrm{~mL}$ of Chitosan/ $\beta$ -

glycerophosphate/Hyaluronic Acid into rabbits' left TMJs

- control group (right TMJs) injection of

$0.2 \mathrm{~mL}$ of Hyaluronic Acid $(10 \mathrm{mg} / \mathrm{mL})$

6 healthy adult goats:

- control group (2 goats) - retrodiscal

tissues were cut off without any

Li et al. [120] Animal study

\section{other procedures}

- experimental group (4 goats)—retrodiscal

tissues were cut off and chitosan

membrane was placed between the

articular disc and the condyle
Endpoint: 7 days

Hydrogel scaffolds were able to retain significantly more of injected HA in the rabbits TMJs after 7 days compared to the control.

HA: hyaluronic acid; MIO: maximal interincisal opening; PRP: platelet-rich plasma; TMD: temporomandibular joint disorder; TMJ: temporomandibular joint.

\section{Conclusions}

Chitosan presents many biological properties and therefore it can be widely used in several branches of medicine and dentistry. One of the most interesting properties of chitosan is its ability to promote wound healing, which makes chitosan useful in bone tissue engineering. There are currently inadequate numbers of clinical studies to assess the efficacy of chitosan for the treatment of TMD. According to only one clinical study, chitosan was effective in the treatment of TMD; however, better clinical results were obtained with platelet-rich plasma. Future perspectives should encompass assessment of the clinical efficacy of chitosan in the treatment of TMD and therefore further randomized, doubleblind, and long-term clinical studies should be performed.

Author Contributions: Conceptualization, M.D.; methodology, M.D.; validation, M.D., L.L. and K.M.; formal analysis, M.D.; investigation, M.D., L.L. and K.M.; resources, M.D., L.L. and K.M.; writing—original draft preparation, M.D., L.L. and K.M.; writing—review and editing, M.D., A.Z. and E.P.; supervision, M.D., A.Z. and E.P.; project administration, M.D. All authors have read and agreed to the published version of the manuscript.

Funding: This research received no external funding.

Institutional Review Board Statement: Not applicable.

Informed Consent Statement: Not applicable.

Data Availability Statement: All data are contained within the article.

Acknowledgments: We would like to thank BioRender.com for the possibility of creating Figures 5 and 6 . 
Conflicts of Interest: Marcin Derwich is employed at ORTODENT. Marcin Derwich have no economical or commercial interest to disclaim. Lukasz Lassmann is employed at Dental Sense. Lukasz Lassmann have no economical or commercial interest to disclaim. The other authors declare no conflict of interest.

\section{References}

1. Ohrbach, R.; Bair, E.; Fillingim, R.B.; Gonzalez, Y.; Gordon, S.M.; Lim, P.F.; Ribeiro-Dasilva, M.; Diatchenko, L.; Dubner, R.; Greenspan, J.D.; et al. Clinical orofacial characteristics associated with risk of first-onset TMD: The OPPERA prospective cohort study. J. Pain 2013, 14 (Suppl. 12), T33-T50. [CrossRef]

2. Valesan, L.F.; Da-Cas, C.D.; Réus, J.C.; Denardin, A.C.S.; Garanhani, R.R.; Bonotto, D.; Januzzi, E.; de Souza, B.D.M. Prevalence of temporomandibular joint disorders: A systematic review and meta-analysis. Clin. Oral Investig. 2021, 25, 441-453. [CrossRef] [PubMed]

3. Dworkin, S.F.; Von Korff, M.; LeResche, L. Multiple pains and psychiatric disturbance. An epidemiologic investigation. Arch. Gen. Psychiatry. 1990, 47, 239-244. [CrossRef] [PubMed]

4. List, T.; Dworkin, S.F. Comparing TMD diagnoses and clinical findings at Swedish and US TMD centers using research diagnostic criteria for temporomandibular disorders. J. Orofac. Pain 1996, 10, 240-253.

5. John, M.T.; Reissmann, D.R.; Schierz, O.; Wassell, R.W. Oral health-related quality of life in patients with temporomandibular disorders. J. Orofac. Pain 2007, 21, 46-54. [PubMed]

6. Türp, J.C.; Motschall, E.; Schindler, H.J.; Heydecke, G. In patients with temporomandibular disorders, do particular interventions influence oral health-related quality of life? A qualitative systematic review of the literature. Clin. Oral Implant. Res. 2007, 18 (Suppl. 3), 127-137. [CrossRef]

7. Suvinen, T.I.; Reade, P.C.; Kemppainen, P.; Könönen, M.; Dworkin, S.F. Review of aetiological concepts of temporomandibular pain disorders: Towards a biopsychosocial model for integration of physical disorder factors with psychological and psychosocial illness impact factors. Eur. J. Pain 2005, 9, 613-633. [CrossRef] [PubMed]

8. Tanaka, E.; Detamore, M.S.; Mercuri, L.G. Degenerative disorders of the temporomandibular joint: Etiology, diagnosis, and treatment. J. Dent. Res. 2008, 87, 296-307. [CrossRef]

9. Nitzan, D.W.; Nitzan, U.; Dan, P.; Yedgar, S. The role of hyaluronic acid in protecting surface-active phospholipids from lysis by exogenous phospholipase A(2). Rheumatology 2001, 40, 336-340. [CrossRef]

10. Nitzan, D.W. The process of lubrication impairment and its involvement in temporomandibular joint disc displacement: A theoretical concept. J. Oral Maxillofac. Surg. 2001, 59, 36-45. [CrossRef]

11. Nitzan, D.W.; Marmary, Y. The "anchored disc phenomenon": A proposed etiology for sudden-onset, severe, and persistent closed lock of the temporomandibular joint. J. Oral Maxillofac. Surg. 1997, 55, 797-802. [CrossRef]

12. Zardeneta, G.; Milam, S.B.; Schmitz, J.P. Iron-dependent generation of free radicals: Plausible mechanisms in the progressive deterioration of the temporomandibular joint. J. Oral Maxillofac. Surg. 2000, 58, 302-308. [CrossRef]

13. Nitzan, D.W.; Etsion, I. Adhesive force: The underlying cause of the disc anchorage to the fossa and/or eminence in the temporomandibular joint-A new concept. Int. J. Oral Maxillofac. Surg. 2002, 31, 94-99. [CrossRef] [PubMed]

14. Nitzan, D.W. 'Friction and adhesive forces'-Possible underlying causes for temporomandibular joint internal derangement. Cells Tissues Organs. 2003, 174, 6-16. [CrossRef] [PubMed]

15. Lin, W.; Mashiah, R.; Seror, J.; Kadar, A.; Dolkart, O.; Pritsch, T.; Goldberg, R.; Klein, J. Lipid-hyaluronan synergy strongly reduces intrasynovial tissue boundary friction. Acta Biomater. 2019, 83, 314-321. [CrossRef] [PubMed]

16. Smith, P.; Ziolek, R.M.; Gazzarrini, E.; Owen, D.M.; Lorenz, C.D. On the interaction of hyaluronic acid with synovial fluid lipid membranes. Phys. Chem. Chem. Phys. 2019, 21, 9845-9857. [CrossRef]

17. Hilšer, P.; Suchánková, A.; Mendová, K.; Eleršič Filipič, K.; Daniel, M.; Vrbka, M. A new insight into more effective viscosupplementation based on the synergy of hyaluronic acid and phospholipids for cartilage friction reduction. Biotribology 2021, 25, 100166. [CrossRef]

18. Milam, S.B.; Schmitz, J.P. Molecular biology of temporomandibular joint disorders: Proposed mechanisms of disease. J. Oral Maxillofac. Surg. 1995, 53, 1448-1454. [CrossRef]

19. Milam, S.B.; Zardeneta, G.; Schmitz, J.P. Oxidative stress and degenerative temporomandibular joint disease: A proposed hypothesis. J. Oral Maxillofac. Surg. 1998, 56, 214-223. [CrossRef]

20. Yamaguchi, A.; Tojyo, I.; Yoshida, H.; Fujita, S. Role of hypoxia and interleukin-1beta in gene expressions of matrix metalloproteinases in temporomandibular joint disc cells. Arch. Oral Biol. 2005, 50, 81-87. [CrossRef] [PubMed]

21. Stegenga, B.; de Bont, L.G.; Boering, G.; van Willigen, J.D. Tissue responses to degenerative changes in the temporomandibular joint: A review. J. Oral Maxillofac. Surg. 1991, 49, 1079-1088. [CrossRef]

22. Martin-Granizo, R.; Correa-Muñoz, D.C. Chondromalacia as pathological finding in arthroscopy of the temporomandibular joint: A retrospective study. J. Craniomaxillofac. Surg. 2018, 46, 82-89. [CrossRef] [PubMed]

23. Dijkgraaf, L.C.; de Bont, L.G.; Boering, G.; Liem, R.S. The structure, biochemistry, and metabolism of osteoarthritic cartilage: A review of the literature. J. Oral Maxillofac. Surg. 1995, 53, 1182-1192. [CrossRef]

24. Al-Moraissi, E.A.; Wolford, L.M.; Ellis, E.; Neff, A. The hierarchy of different treatments for arthrogenous temporomandibular disorders: A network meta-analysis of randomized clinical trials. J. Craniomaxillofac. Surg. 2020, 48, 9-23. [CrossRef] [PubMed] 
25. Derwich, M.; Mitus-Kenig, M.; Pawlowska, E. Interdisciplinary Approach to the Temporomandibular Joint Osteoarthritis-Review of the Literature. Medicina 2020, 56, 225. [CrossRef] [PubMed]

26. Derwich, M.; Mitus-Kenig, M.; Pawlowska, E. Mechanisms of Action and Efficacy of Hyaluronic Acid, Corticosteroids and Platelet-Rich Plasma in the Treatment of Temporomandibular Joint Osteoarthritis-A Systematic Review. Int. J. Mol. Sci. 2021, 22, 7405. [CrossRef] [PubMed]

27. Thein-Han, W.W.; Misra, R.D. Biomimetic chitosan-nanohydroxyapatite composite scaffolds for bone tissue engineering. Acta Biomater. 2009, 5, 1182-1197. [CrossRef] [PubMed]

28. Hu, L.; Meng, X.; Xing, R.; Liu, S.; Chen, X.; Qin, Y.; Yu, H.; Li, P. Design, synthesis and antimicrobial activity of 6-N-substituted chitosan derivatives. Bioorg. Med. Chem. Lett. 2016, 26, 4548-4551. [CrossRef]

29. Sukpaita, T.; Chirachanchai, S.; Pimkhaokham, A.; Ampornaramveth, R.S. Chitosan-Based Scaffold for Mineralized Tissues Regeneration. Mar. Drugs. 2021, 19, 551. [CrossRef]

30. Elieh-Ali-Komi, D.; Hamblin, M.R. Chitin and Chitosan: Production and Application of Versatile Biomedical Nanomaterials. Int. J. Adv. Res. 2016, 4, 411-427.

31. Chocholata, P.; Kulda, V.; Babuska, V. Fabrication of Scaffolds for Bone-Tissue Regeneration. Materials 2019, 12, 568. [CrossRef] [PubMed]

32. Liu, Z.; Mo, X.; Ma, F.; Li, S.; Wu, G.; Tang, B.; Lin, L. Synthesis of carboxymethyl chitosan-strontium complex and its therapeutic effects on relieving osteoarthritis. Carbohydr. Polym. 2021, 261, 117869. [CrossRef] [PubMed]

33. Liu, J.; Yang, B.; Li, M.; Li, J.; Wan, Y. Enhanced dual network hydrogels consisting of thiolated chitosan and silk fibroin for cartilage tissue engineering. Carbohydr. Polym. 2020, 227, 115335. [CrossRef] [PubMed]

34. Lu, K.Y.; Lin, Y.C.; Lu, H.T.; Ho, Y.C.; Weng, S.C.; Tsai, M.L.; Mi, F.L. A novel injectable in situ forming gel based on carboxymethyl hexanoyl chitosan/hyaluronic acid polymer blending for sustained release of berberine. Carbohydr. Polym. 2019, 206, 664-673. [CrossRef]

35. Wang, Y.; Yuan, X.; Yu, K.; Meng, H.; Zheng, Y.; Peng, J.; Lu, S.; Liu, X.; Xie, Y.; Qiao, K. Fabrication of nanofibrous microcarriers mimicking extracellular matrix for functional microtissue formation and cartilage regeneration. Biomaterials 2018, 171, 118-132. [CrossRef]

36. Satitsri, S.; Muanprasat, C. Chitin and Chitosan Derivatives as Biomaterial Resources for Biological and Biomedical Applications. Molecules 2020, 25, 5961. [CrossRef]

37. Patrulea, V.; Ostafe, V.; Borchard, G.; Jordan, O. Chitosan as a starting material for wound healing applications. Eur. J. Pharm. Biopharm. 2015, 97, 417-426. [CrossRef]

38. Xu, W.; Mohan, A.; Pitts, N.L.; Udenigwe, C.; Mason, B. Bile acid-binding capacity of lobster shell-derived chitin, chitosan and chitooligosaccharides. Food Biosci. 2020, 33, 100476. [CrossRef]

39. Wang, M.; Chen, L.J.; Ni, J.; Weng, J.; Yue, C.Y. Manufacture and evaluation of bioactive and biodegradable materials and scaffolds for tissue engineering. J. Mater. Sci. Mater. Med. 2001, 12, 855-860. [CrossRef]

40. Hahn, T.; Tafi, E.; Paul, A.; Salvia, R.; Falabella, P.; Zibek, S. Current state of chitin purification and chitosan production from insects. J. Chem. Technol. Biotechnol. 2020, 95, 2775-2795. [CrossRef]

41. Synowiecki, J.; Al-Khateeb, N.A. Production, properties, and some new applications of chitin and its derivatives. Crit. Rev. Food Sci. Nutr. 2003, 43, 145-171. [CrossRef]

42. Cheung, R.C.; Ng, T.B.; Wong, J.H.; Chan, W.Y. Chitosan: An Update on Potential Biomedical and Pharmaceutical Applications. Mar. Drugs 2015, 13, 5156-5186. [CrossRef]

43. Kaczmarek, M.B.; Struszczyk-Swita, K.; Li, X.; Szczęsna-Antczak, M.; Daroch, M. Enzymatic Modifications of Chitin, Chitosan, and Chitooligosaccharides. Front. Bioeng. Biotechnol. 2019, 7, 243. [CrossRef] [PubMed]

44. Grifoll-Romero, L.; Pascual, S.; Aragunde, H.; Biarnés, X.; Planas, A. Chitin Deacetylases: Structures, Specificities, and Biotech Applications. Polymers 2018, 10, 352. [CrossRef]

45. Pakizeh, M.; Moradi, A.; Ghassemi, T. Chemical extraction and modification of chitin and chitosan from shrimp shells. Eur. Polym. J. 2021, 159, 110709. [CrossRef]

46. Morin-Crini, N.; Lichtfouse, E.; Torri, G.; Crini, G. Applications of chitosan in food, pharmaceuticals, medicine, cosmetics, agriculture, textiles, pulp and paper, biotechnology, and environmental chemistry. Environ. Chem. Lett. 2019, 17, 1667-1692. [CrossRef]

47. Batista, A.C.L.; Souza, F.E.; Paiva, W.S. Review of fungal chitosan: Past, present and perspectives in Brazil. Polimeros 2018, $28,3$. [CrossRef]

48. Younes, I.; Rinaudo, M. Chitin and chitosan preparation from marine sources. Structure, properties and applications. Mar. Drugs 2015, 13, 1133. [CrossRef]

49. Huang, C.L.; Chen, Y.B.; Lo, Y.L.; Lin, Y.H. Development of chitosan/ $\beta$-glycerophosphate/glycerol hydrogel as a thermosensitive coupling agent. Carbohydr. Polym. 2016, 147, 409-414. [CrossRef]

50. Islam, S.; Bhuiyan, M.A.R.; Islam, M.N. Chitin and Chitosan: Structure, Properties and Applications in Biomedical Engineering J. Polym. Environ. 2017, 27, 854-866. [CrossRef]

51. Thadathil, N.; Velappan, S.P. Recent developments in chitosanase research and its biotechnological applications: A review. Food Chem. 2014, 150, 392-399. [CrossRef] [PubMed] 
52. Di Martino, A.; Sittinger, M.; Risbud, M.V. Chitosan: A versatile biopolymer for orthopaedic tissue-engineering. Biomaterials 2005, 26, 5983-5990. [CrossRef] [PubMed]

53. Ma, F.; Wang, Y.; Yang, G. The Modulation of Chitosan-DNA Interaction by Concentration and pH in Solution. Polymers 2019, 11, 646. [CrossRef] [PubMed]

54. Bravo-Anaya, L.M.; Soltero, J.F.; Rinaudo, M. DNA/chitosan electrostatic complex. Int. J. Biol. Macromol. 2016, 88, 345-353. [CrossRef] [PubMed]

55. Goldmann, K.; Ensminger, S.M.; Spriewald, B.M. Oral gene application using chitosan-DNA nanoparticles induces transferable tolerance. Clin. Vaccine Immunol. 2012, 19, 1758-1764. [CrossRef]

56. Mao, H.Q.; Roy, K.; Troung-Le, V.L.; Janes, K.A.; Lin, K.Y.; Wang, Y.; August, J.T.; Leong, K.W. Chitosan-DNA nanoparticles as gene carriers: Synthesis, characterization and transfection efficiency. J. Control. Release 2001, 70, 399-421. [CrossRef]

57. Moeini, A.; Pedram, P.; Makvandi, P.; Malinconico, M.; Gomez d'Ayala, G. Wound healing and antimicrobial effect of active secondary metabolites in chitosan-based wound dressings: A review. Carbohydr. Polym. 2020, 233, 115839. [CrossRef]

58. Ma, Z.; Kotaki, M.; Inai, R.; Ramakrishna, S. Potential of nanofiber matrix as tissue-engineering scaffolds. Tissue Eng. 2005, 11, 101-109. [CrossRef]

59. Aranaz, I.; Alcántara, A.R.; Civera, M.C.; Arias, C.; Elorza, B.; Heras Caballero, A.; Acosta, N. Chitosan: An Overview of Its Properties and Applications. Polymers 2021, 13, 3256. [CrossRef]

60. Valachová, K.; Šoltés, L. Versatile Use of Chitosan and Hyaluronan in Medicine. Molecules 2021, 26, 1195. [CrossRef]

61. Bayer, I.S. Hyaluronic Acid and Controlled Release: A Review. Molecules. 2020, 25, 2649. [CrossRef]

62. Vigetti, D.; Karousou, E.; Viola, M.; Deleonibus, S.; De Luca, G.; Passi, A. Hyaluronan: Biosynthesis and signaling. Biochim. Biophys. Acta. 2014, 1840, 2452-2459. [CrossRef]

63. Salwowska, N.M.; Bebenek, K.A.; Żądło, D.A.; Wcisło-Dziadecka, D.L. Physiochemical properties and application of hyaluronic acid: A systematic review. J. Cosmet. Dermatol. 2016, 15, 520-526. [CrossRef] [PubMed]

64. Snetkov, P.; Zakharova, K.; Morozkina, S.; Olekhnovich, R.; Uspenskaya, M. Hyaluronic Acid: The Influence of Molecular Weight on Structural, Physical, Physico-Chemical, and Degradable Properties of Biopolymer. Polymers 2020, 12, 1800. [CrossRef] [PubMed]

65. Turley, E.A.; Noble, P.W.; Bourguignon, L.Y. Signaling properties of hyaluronan receptors. J. Biol. Chem. 2002, $277,4589-4592$. [CrossRef]

66. Litwiniuk, M.; Krejner, A.; Speyrer, M.S.; Gauto, A.R.; Grzela, T. Hyaluronic Acid in Inflammation and Tissue Regeneration Wounds 2016, 28, 78-88. [PubMed]

67. Kim, H.; Jeong, H.; Han, S.; Beack, S.; Hwang, B.W.; Shin, M.; Oh, S.S.; Hahn, S.K. Hyaluronate and its derivatives for customized biomedical applications. Biomaterials 2017, 123, 155-171. [CrossRef]

68. Juncan, A.M.; Moisa, D.; Santini, A.; Morgovan, C.; Rus, L.-L.; Vonica-Tincu, A.L.; Loghin, F. Advantages of Hyaluronic Acid and Its Combination with Other Bioactive Ingredients in Cosmeceuticals. Molecules 2021, 26, 4429. [CrossRef]

69. Casale, M.; Moffa, A.; Vella, P.; Sabatino, L.; Capuano, F.; Salvinelli, B.; Lopez, M.A.; Carinci, F.; Salvinelli, F. Hyaluronic acid: Perspectives in dentistry. A systematic review. Int. J. Immunopathol. Pharmacol. 2016, 29, 572-582. [CrossRef]

70. Kim, J.; Chang, J.Y.; Kim, Y.Y.; Kim, M.J.; Kho, H.S. Effects of molecular weight of hyaluronic acid on its viscosity and enzymatic activities of lysozyme and peroxidase. Arch. Oral Biol. 2018, 89, 55-64. [CrossRef]

71. Huang, G.; Chen, J. Preparation and applications of hyaluronic acid and its derivatives. Int. J. Biol. Macromol. 2019, 125, 478-484. [CrossRef]

72. Oh, E.J.; Park, K.; Kim, K.S.; Kim, J.; Yang, J.A.; Kong, J.H.; Lee, M.Y.; Hoffman, A.S.; Hahn, S.K. Target specific and long-acting delivery of protein, peptide, and nucleotide therapeutics using hyaluronic acid derivatives. J. Control. Release 2010, 141, 2-12. [CrossRef]

73. Gupta, R.C.; Lall, R.; Srivastava, A.; Sinha, A. Hyaluronic Acid: Molecular Mechanisms and Therapeutic Trajectory. Front. Vet. Sci. 2019, 6, 192. [CrossRef]

74. Allan, C.R.; Hadwiger, L.A. The fungicidal effect of chitosan on fungi of varying cell wall composition. Exp. Mycol. 1979, 3, 285-287. [CrossRef]

75. Sudarshan, N.R.; Hoover, D.G.; Knorr, D. Antibacterial action of chitosan. Food Biotechnol. 1992, 6, 257-272. [CrossRef]

76. Zheng, L.Y.; Zhu, J.F. Study on Antimicrobial Activity of Chitosan with Different Molecular Weights. Carbohydr. Polym. 2003, 54, 527-530. [CrossRef]

77. Beanes, S.R.; Dang, C.; Soo, C.; Ting, K. Skin repair and scar formation: The central role of TGF-beta. Expert Rev. Mol. Med. 2003, 5, 1-22. [CrossRef]

78. Uragami, T.; Tokura, S. Material Science of Chitin and Chitosan, 1st ed.; Springer: New York, NY, USA, 2006; pp. 51-79.

79. Chen, W.Y.; Rogers, A.A.; Lydon, M.J. Characterization of biologic properties of wound fluid collected during early stages of wound healing. J. Invest. Dermatol. 1992, 99, 559-564. [CrossRef] [PubMed]

80. Kim, M.M.; Kim, S.K. Chitooligosaccharides inhibit activation and expression of matrix metalloproteinase-2 in human dermal fibroblasts. FEBS Lett. 2006, 580, 2661-2666. [CrossRef]

81. Gorzelanny, C.; Pöppelmann, B.; Strozyk, E.; Moerschbacher, B.M.; Schneider, S.W. Specific interaction between chitosan and matrix metalloprotease 2 decreases the invasive activity of human melanoma cells. Biomacromolecules 2007, 8, 3035-3040. [CrossRef] 
82. Shikhman, A.R.; Amiel, D.; D’Lima, D.; Hwang, S.B.; Hu, C.; Xu, A.; Hashimoto, S.; Kobayashi, K.; Sasho, T.; Lotz, M.K. Chondroprotective activity of N-acetylglucosamine in rabbits with experimental osteoarthritis. Ann. Rheum. Dis. 2005, 64, 89-94. [CrossRef] [PubMed]

83. Murphy, K. Autoimmunity and Transplantation. In Janeway's Immunobiology, 8th ed.; Garland Science, Taylor \& Francis Group: New York, NY, USA, 2012; Volume 1, pp. 637-638.

84. Mirahmadi, F.; Tafazzoli-Shadpour, M.; Shokrgozar, M.A.; Bonakdar, S. Enhanced mechanical properties of thermosensitive chitosan hydrogel by silk fibers for cartilage tissue engineering. Mater. Sci. Eng. C Mater. Biol. Appl. 2013, 33, $4786-4794$. [CrossRef] [PubMed]

85. Suh, J.K.; Matthew, H.W. Application of chitosan-based polysaccharide biomaterials in cartilage tissue engineering: A review. Biomaterials 2000, 21, 2589-2598. [CrossRef] [PubMed]

86. Kumar, M. A review of chitin and chitosan applications. React. Funct. Polym. 2000, 46, 1-27. [CrossRef]

87. Zhao, M.; Chen, Z.; Liu, K.; Wan, Y.Q.; Li, X.D.; Luo, X.W.; Bai, Y.G.; Yang, Z.L.; Feng, G. Repair of articular cartilage defects in rabbits through tissue-engineered cartilage constructed with chitosan hydrogel and chondrocytes. J. Zhejiang Univ. Sci. B. 2015, 16, 914-923. [CrossRef]

88. Zhao, W.; Jin, X.; Cong, Y.; Liu, Y.; Fu, J. Degradable natural polymer hydrogels for articular cartilage tissue engineering. J. Chem. Technol. Biotechnol. 2013, 88, 327-339. [CrossRef]

89. Hao, T.; Wen, N.; Cao, J.K.; Wang, H.B.; Lü, S.H.; Liu, T.; Lin, Q.X.; Duan, C.M.; Wang, C.Y. The support of matrix accumulation and the promotion of sheep articular cartilage defects repair in vivo by chitosan hydrogels. Osteoarthr. Cartil. 2010, 18, 257-265. [CrossRef]

90. Comblain, F.; Rocasalbas, G.; Gauthier, S.; Henrotin, Y. Chitosan: A promising polymer for cartilage repair and viscosupplementation. Biomed. Mater. Eng. 2017, 28, S209-S215. [CrossRef]

91. Howling, G.I.; Dettmar, P.W.; Goddard, P.A.; Hampson, F.C.; Dornish, M.; Wood, E.J. The effect of chitin and chitosan on the proliferation of human skin fibroblasts and keratinocytes in vitro. Biomaterials 2001, 22, 2959-2966. [CrossRef]

92. Qi, L.; Xu, Z. In vivo antitumor activity of chitosan nanoparticles. Bioorg. Med. Chem. Lett. 2006, 16, 4243-4245. [CrossRef]

93. Dass, C.R.; Choong, P.F. The use of chitosan formulations in cancer therapy. J. Microencapsul. 2008, 25, 275-279. [CrossRef] [PubMed]

94. Tokoro, A.; Tatewaki, N.; Suzuki, K.; Mikami, T.; Suzuki, S.; Suzuki, M. Growth-inhibitory effect of hexa-N-acetylchitohexaose and chitohexaose against Meth-A solid tumor. Chem. Pharm. Bull. 1988, 36, 784-790. [CrossRef] [PubMed]

95. Murata, J.; Saiki, I.; Nishimura, S.; Nishi, N.; Tokura, S.; Azuma, I. Inhibitory effect of chitin heparinoids on the lung metastasis of B16-BL6 melanoma. Jpn. J. Cancer Res. 1989, 80, 866-872. [CrossRef] [PubMed]

96. Hasegawa, M.; Yagi, K.; Iwakawa, S.; Hirai, M. Chitosan induces apoptosis via caspase-3 activation in bladder tumor cells. Jpn. J. Cancer Res. 2001, 92, 459-466. [CrossRef]

97. Khor, E.; Lim, L.Y. Implantable applications of chitin and chitosan. Biomaterials 2003, 24, 2339-2349. [CrossRef]

98. Hamedi, H.; Moradi, S.; Hudson, S.M.; Tonelli, A.E. Chitosan based hydrogels and their applications for drug delivery in wound dressings: A review. Carbohydr. Polym. 2018, 199, 445-460. [CrossRef]

99. Muzzarelli, R.A.A. Chitins and chitosans for the repair of wounded skin, nerve, cartilage and bone. Carbohydr. Polym. 2009, 76, 167-182. [CrossRef]

100. Ong, S.Y.; Wu, J.; Moochhala, S.M.; Tan, M.H.; Lu, J. Development of a chitosan-based wound dressing with improved hemostatic and antimicrobial properties. Biomaterials 2008, 29, 4323-4332. [CrossRef]

101. Ishihara, M.; Nakanishi, K.; Ono, K.; Sato, M.; Kikuchi, M.; Saito, Y.; Yura, H.; Matsui, T.; Hattori, H.; Uenoyama, M.; et al. Photocrosslinkable chitosan as a dressing for wound occlusion and accelerator in healing process. Biomaterials 2002, 23, 833-840. [CrossRef]

102. Chung, Y.C.; Su, Y.P.; Chen, C.C.; Jia, G.; Wang, H.L.; Wu, J.C.; Lin, J.G. Relationship between antibacterial activity of chitosan and surface characteristics of cell wall. Acta Pharmacol. Sin. 2004, 25, 932-936.

103. Visveswaraiah, P.M.; Prasad, D.; Johnson, S. Chitosan A novel way to intervene in enamel demineralization-An in vitro study. Int. J. Curr. Microbiol. Appl. Sci. 2014, 3, 617.

104. Costa, E.M.; Silva, S.; Madureira, A.R.; Cardelle-Cobas, A.; Tavaria, F.K.; Pintado, M.M. A comprehensive study into the impact of a chitosan mouthwash upon oral microorganism's biofilm formation in vitro. Carbohydr. Polym. 2014, 101, 1081-1086. [CrossRef] [PubMed]

105. Di Giulio, M.; Di Bartolomeo, S.; Di Campli, E.; Sancilio, S.; Marsich, E.; Travan, A.; Cataldi, A.; Cellini, L. The Effect of a Silver Nanoparticle Polysaccharide System on Streptococcal and Saliva-Derived Biofilms. Int. J. Mol. Sci. 2013, 14, 13615-13625. [CrossRef] [PubMed]

106. Fakhri, E.; Eslami, H.; Maroufi Ganbarov, K.; Yousefi, M.; Tanomand, A.; Yousefi, B.; Mahmoudi, S.; Kafil, H.S. Chitosan biomaterials application in dentistry. Int. J. Biol. Macromol. 2020, 162, 956-974. [CrossRef] [PubMed]

107. Machut, K.; Zoltowska, A.; Pawlowska, E.; Derwich, M. Plasma Rich in Growth Factors in the Treatment of Endodontic Periapical Lesions in Adult Patients: Case Reports. Int. J. Mol. Sci. 2021, 22, 9458. [CrossRef] 
108. Loyola-Rodríguez, J.P.; Torres-Méndez, F.; Espinosa-Cristobal, L.F.; García-Cortes, J.O.; Loyola-Leyva, A.; González, F.J.; Soto-Barreras, U.; Nieto-Aguilar, R.; Contreras-Palma, G. Antimicrobial activity of endodontic sealers and medications containing chitosan and silver nanoparticles against Enterococcus faecalis. J. Appl. Biomater. Funct. Mater. 2019, 17, 2280800019851771. [CrossRef]

109. Atila, D.; Chen, C.Y.; Lin, C.P.; Lee, Y.L.; Hasirci, V.; Tezcaner, A.; Lin, F.H. In vitro evaluation of injectable Tideglusib-loaded hyaluronic acid hydrogels incorporated with Rg1-loaded chitosan microspheres for vital pulp regeneration. Carbohydr. Polym. 2022, 278, 118976. [CrossRef]

110. Farea, M.; Husein, A.; Halim, A.S.; Abdullah, N.A.; Mokhtar, K.I.; Lim, C.K.; Berahim, Z.; Mokhtar, K. Synergistic effects of chitosan scaffold and TGF $\beta 1$ on the proliferation and osteogenic differentiation of dental pulp stem cells derived from human exfoliated deciduous teeth. Arch. Oral Biol. 2014, 59, 1400-1411. [CrossRef]

111. Tanikonda, R.; Ravi, R.K.; Kantheti, S.; Divella, S. Chitosan: Applications in Dentistry. Trends Biomater. Artif. Organs 2014, 28, $74-78$.

112. Ho, M.H.; Hsieh, C.C.; Hsiao, S.H.; Thien, D.V.H. Fabrication of asymmetric chitosan GTR membranes for the treatment of periodontal disease. Carbohydr. Polym. 2010, 79, 955-963. [CrossRef]

113. Ji, Q.X.; Deng, J.; Xing, X.M.; Yuan, C.Q.; Yu, X.B.; Xu, Q.C.; Yue, J. Biocompatibility of a chitosan-based injectable thermosensitive hydrogel and its effects on dog periodontal tissue regeneration. Carbohydr. Polym. 2010, 82, 1153-1160. [CrossRef]

114. Needleman, I.G.; Smales, F.C. In vitro assessment of bioadhesion for periodontal and buccal drug delivery. Biomaterials 1995, 16, 617-624. [CrossRef]

115. Sukpaita, T.; Chirachanchai, S.; Suwattanachai, P.; Everts, V.; Pimkhaokham, A.; Ampornaramveth, R.S. In Vivo Bone Regeneration Induced by a Scaffold of Chitosan/Dicarboxylic Acid Seeded with Human Periodontal Ligament Cells. Int. J. Mol. Sci. 2019, 20, 4883. [CrossRef]

116. Su, W.T.; Wu, P.S.; Ko, C.S.; Huang, T.Y. Osteogenic differentiation and mineralization of human exfoliated deciduous teeth stem cells on modified chitosan scaffold. Mater. Sci. Eng. C Mater. Biol. Appl. 2014, 41, 152-160. [CrossRef] [PubMed]

117. Alnufaiy, B.M.; Lambarte, R.N.A.; Al-Hamdan, K.S. The Osteogenetic Potential of Chitosan Coated Implant: An In Vitro Study. J. Stem Cells Regen. Med. 2020, 16, 44-49. [CrossRef]

118. Li, F.L.; Wu, C.B.; Sun, H.J.; Zhou, Q. Comparison of Autologous Platelet-Rich Plasma and Chitosan in the Treatment of Temporomandibular Joint Osteoarthritis: A Retrospective Cohort Study. J. Oral Maxillofac. Surg. 2021, 79, 324-332. [CrossRef]

119. Talaat, W.M.; Haider, M.; Kawas, S.A.; Kandil, N.G.; Harding, D.R. Chitosan-Based Thermosensitive Hydrogel for Controlled Drug Delivery to the Temporomandibular Joint. J. Craniofac. Surg. 2016, 27, 735-740. [CrossRef]

120. Li, H.P.; Sun, S.F.; Fan, B.T.; Shen, P.; Zheng, J.S.; Zhang, S.Y. Prevention of adhesions in the temporomandibular joint by the use of chitosan membrane in goats. Br. J. Oral Maxillofac. Surg. 2017, 55, 26-30. [CrossRef]

121. Bousnaki, M.; Bakopoulou, A.; Papadogianni, D.; Barkoula, N.M.; Alpantaki, K.; Kritis, A.; Chatzinikolaidou, M.; Koidis, P. Fibro/chondrogenic differentiation of dental stem cells into chitosan/alginate scaffolds towards temporomandibular joint disc regeneration. J. Mater. Sci. Mater. Med. 2018, 29, 97. [CrossRef]

122. Wu, Y.; Gong, Z.; Li, J.; Meng, Q.; Fang, W.; Long, X. The pilot study of fibrin with temporomandibular joint derived synovial stem cells in repairing TMJ disc perforation. Biomed. Res. Int. 2014, 2014, 454021. [CrossRef] 